\title{
PENINGKATAN GIZI PROTEIN HEWANI MELALUI KETERAMPILAN PEMBUATAN BASO IKAN DI RW 07 DESA CINTAMULYA, JATINANGOR
}

\author{
Heti Herawati', dan Fitri Perdana ${ }^{2}$ \\ ${ }^{1}$ Fakultas Perikanan dan Ilmu Kelautan, Universitas Padjadjaran \\ ${ }^{2}$ Fakultas Ilmu Komunikasi, Universitas Padjadjaran \\ E-mail: h.herawati@unpad.ac.id
}

\begin{abstract}
ABSTRAK. Desa Cintamulya merupakan salah satu desa yang berada pada kawasan industri. Kawasan industri setidaknya dapat mempengaruhi kehidupan masyarakat pada umumnya baik masyarakat pedesaan maupun perkotaan, hal ini terlihat dari banyaknya pengaruh yang kuat dari ranah kawasan industri terhadap peningkatan kesejahteraan sosial masyarakat, pola hidup, kebiasaan, kebudayaan yang dapat mempengaruhi berbagai aspek nilai - nilai sosial yang kuat pada masyarakat. Namun pada saat ini banyak juga penduduk di Desa Cintamulya yang tidak memiliki pekerjaan dan penghasilan yang mencukupi untuk memenuhi kebutuhan gizi yang sesuai terutama untuk anak-anak dikarenakan biasanya pabrik-pabrik industri hanya menerima pegawai diusia produktif, sementara banyak warga di Desa Cintamulya yang berusia lebih dari 40 tahun. Dengan memperhatikan kondisi tersebut, maka perlu adanya penyuluhan dan praktek langsung pembuatan baso ikan sebagai salah satu bentuk usaha untuk meningkatkan gizi protein hewani masyarakat terutama anakanak. Tujuan dari kegiatan ini diharapkan dapat meningkatkan gizi masyarakat juga memberikan peluang usaha bagi masyarakat Desa Cintamulya agar mendapatkan tambahan penghasilan. Metode yang digunakan adalah dengan pemberian materi, kemudian diskusi, dan praktik. Kegiatan pelatihan dipandu oleh narasumber sebagai fasilitator pelatihan dengan praktik secara langsung. Target peserta pelatihan seperti direncanakan sebelumnya adalah 25 ibu-ibu kader PKK dan ibu rumah tangga, dalam pelaksanaannya, kegiatan ini diikuti oleh 44 orang peserta. Dengan demikian dapat dikatakan bahwa target peserta tercapai lebih dari $100 \%$. Angka tersebut menunjukkan bahwa kegiatan PPMP OKK dilihat dari jumlah peserta yang mengikuti dapat dikatakan berhasil/s sukses.
\end{abstract}

Kata kunci: Desa Cintamulya, Baso ikan, Nutrisi

\begin{abstract}
Cintamulya Village is one of the villages in the industrial area. Industrial zones can at least affect the lives of people in general both rural and urban communities, as can be seen from the many strong influences of the industrial area's realm towards improving the social welfare of society, lifestyle, customs, the culture. However, at this time many residents in Cintamulya village who do not have enough jobs and income to meet the appropriate nutritional needs, especially for children because usually industrial factories only accept employees in productive age, while many residents in the village of Cintamulya who are over age from 40 years. About these conditions, it is necessary to counsel and direct practice of making fish meatball as one form of business to improve the nutrition of animal protein, especially children. The purpose of this activity is expected to improve the nutrition of the community also provides business opportunities for the people of Desa Cintamuly a to get additional income. The method used is by giving the material, then the discussion, and practice. Training activities are guided by resource persons as training facilitators with direct practice. The target of the trainees as previously planned is 25 PKK cadre mothers and housewives, in its implementation, this activity was followed by 44 participants. Thus it can be said that the target participants reached more than $100 \%$. The figure shows that the PPMP OKK activity seen from the number of participants who followed can be said to be successful.
\end{abstract}

Key words: Cintamulya Village, Fish ball, nutrition

\section{PENDAHULUAN}

Desa Cintamulya merupakan salah satu desa yang berada pada kawasan industri di daerah Kabupaten Bandung yang berbatasan dengan Kabupaten Sumedang. Di desa tersebut terdapat salah satu industri terbesar di Asia Tenggara, dengan jumlah pekerja mencapai lebih dari 35 ribu orang yang berasal dari luar daerah. Perusahaan yang berdiri di atas lahan seluas 120 hektar di Kecamatan Cimanggung (Desa Mangunarga-Desa Cisempur) dan Kecamatan Jatinangor (Desa Cintamulya) tersebut, berlokasi di Jalan Raya Bandung-Garut, yang menjadikan wilayah tersebut menjadi sebuah kawasan industri. Sehingga tidak sedikit pengaruh interaksi dan perilaku yang mempengaruhi solidaritas sosial masyarakatnya karena terpengaruh oleh kegiatan industri.

PadaawalnyaDesaCintaMulyamerupakankawasan agraris dan penduduknya memiliki mata pencaharian sebagai petani. Namun semenjak adanya perubahan orientasi kawasan Kecamatan Cikeruh (sebelum bernama Kecamatan Jatinangor) menjadi kawasan pendidikan dan industri, mata pencaharian utama penduduk Desa Cinta Mulya mengalami perubahan. Dengan dibangunnya industri di wilayah Desa Cinta Mulya dan sekitarnya, terjadi alih fungsi lahan dari lahan pertanian menjadi lahan bangunan pabrik. Sehingga penduduk yang tadinya memiliki mata pencaharian sebagai petani mengalami kehilangan lahan garapan, yang kemudian mengubah mata pencahariannya menjadi pegawai pabrik atau buruh. Hanya sebagian kecil saja yang masih memiliki mata pencaharian di sektori pertanian baik sebagai petani maupun buruh tani. Sisa lainnya ada yang bekerja sebagai pengrajin dan pedagang.

Namun pada saat ini banyak juga penduduk di Desa Cintamulya yang tidak memiliki pekerjaan dan penghasilan yang mencukupi untuk memenuhi 
kebutuhan gizi yang sesuai terutama untuk anak-anak dikarenakan biasanya pabrik-pabrik industri hanya menerima pegawai diusia produktif, sementara banyak warga di Desa Cintamulya yang berusia lebih dari 40 tahun yang tidak memungkinkan untuk bekerja di pabrik. Hal tersebut membuat banyak ibu-ibu dan bapak-bapak yang hanya berdiam di rumah tanpa memiliki pekerjaan dan penghasilan. Kondisi ini menimbulkan tuntutan baru akan pemenuhan pangan maupun jajanan yang murah dan bergizi, dan yang papling popular dan disukai adalah baso (Balia dkk, 2014).

Ikan memiliki nilai gizi protein yang cukup tinggi dan selama ini masyarakat Desa Cintamulya mengkonsumsi ikan dalam jumlah yang relative sedikit (Almatsier 2009). Rata-rata masyarakat mengkonsumsi ikan dengan cara hanya digoreng saja sehingga anak-anak kurang menyukainya. Dilihat dari beberapa warga yang memiliki kolam budidaya ikan yang dihasilkan cukup banyak dan jarang juga diolah menjadi jenis makanan lain agar disukai oleh anak-anak, sehingga terlihat sekali bahwa anak-anak kurang mendapatkan asupan gizi protein dari ikan.

Dengan memperhatikan kondisi tersebut, maka tim PPM berkesimpulan bahwa perlu adanya penanggulangan masalah tersebut yaitu dengan memberikan penyuluhan dan praktek langsung pembuatan baso ikan sebagai salah satu bentuk usaha untuk meningkatkan gizi protein hewani masyarakat terutama anak-anak di Desa Cintamulya, Kecamatan Jatinangor, Kabupaten Sumedang. Tujuan dari kegiatan ini selain diharapkan dapat meningkatkan gizi masyarakat juga memberikan peluang usaha bagi masyarakat Desa Cintamulya agar mendapatkan tambahan penghasilan.

\section{METODE}

Metode yang digunakan dalam kegiatan PPMP adalah dengan metode observasi, deskriptif dan partisipasi dengan pendekatan metode yang digunakan dalam kegiatan penyuluhan dan pelatihan yang bersifat 'persuasif-edukatif', yang dimaksudkan untuk memberikan pengetahuan, pemahaman, dan keterampilan dalam membuat produk olahan ikan siap saji (bakso). Pendekatan yang diterapkan dalam merealisasikan program PPMP ini melalui metode participatory approach melalui upaya untuk merealisasikan program PPMP ini agar sesuai dengan tujuan dan outcome yang diharapkan (Widyasanti dkk, 2016). Pelaksanaan kegiatan PPMP OKK ini dilaksanakan pada tanggal 21 Oktober 2017 yang bertempat di Balai Desa Cintamulya dihadiri oleh 44 orang peserta yang berasal dari kader PKK dan ibu rumah tangga di lingkungan RW 07 Desa Cintamulya.

Khalayak sasaran dalam kegiatan PPMP OKK ini adalah para kelompok ibu rumah tangga yang terbentuk dalam Pembinaan Kesejahteraan Keluarga (PKK) di Desa Cintamulya. Kelompok sasaran ini dianggap memerlukan keterampilan dan ibu rumah tangga yang memiliki banyak waktu luang sehingga mendukung dengan adanya kegiatan ini. Dengan adanya kegiatan PPMP OKK ini diharapkan dapat meningkatkan kemampuan kelompok sasaran dalam pengetahuan mengenai pemenuhan gizi protein hewani dari ikan melalui pembuatan baso ikan dan diharapkan pula dapat menjadi agen perubahan dalam masyarakat.

Kegiatan PPMP OKK ini dilakukan oleh dua orang narasumber yang memiliki keahlian dalam mengolah daging ikan menjadi berbagai produk yang bisa memiliki nilai daya jual. Adapun pokok bahasan yang disampaikan dalam kegiatan PPMP OKK ini antara lain:

1. Materi kesehatan mengenai pemenuhan gizi proteim hewani untuk anak-anak, ibu hamil dan menyusui.

2. Teori mengenai berbagai macam pengolahan daging ikan menjadi makanan yang lebih disukai dan bisa juga menjadi peluang usaha untuk meningkatkan perekonomian keluarga.

3. Langkah-langkah pembuatan baso ikan.

4. Latihan langsung pembuatan baso ikan.

5. Evaluasi hasil praktek pembuatan baso ikan.

Rancangan evaluasi yang dilaksanakan terhadap kegiatan pembinaan kepada masyarakat ini antara lain:

1. Evaluasi awal, yaitu pelaksanaan kegiatan survey lapangan untuk menentukan lokasi khalayak sasaran, penentuan dan kesepakatan peserta dari, kader PKK dan ibu rumah tangga.

2. Evaluasi persiapan, yaitu pelaksanaan penentuan jadwal dan tempat kegiatan penyuluhan dan pelatihan serta persiapan instrumen yang diperlukan beserta jumlah bahan baku yang ditentukan.

3. Evaluasi proses, yaitu dengan pelaksanaan kegiatan ceramah, diskusi, simulasi dan pelatihan dengan materi sebagai berikut :

- Pemanfaatan ikan jenis perairan umum hasil budidaya sebagai bahan pangan ikan protein tinggi.

- Keistimewaan ikan tawar sebagai bahan pembuatan bakso ikan.

- Peluang pemasaran produk bakso ikan.

4. Evaluasi hasil, yaitu pelaksanaan penilaian terhadap seluruh kegiatan yang telah diterima oleh peserta khalayak sasaran dengan tolak ukur atas kemampuan peserta untuk menerima materi yang telah disampaikan baik secara teoritis maupun secara teknis.

\section{HASIL DAN PEMBAHASAN}

Berdasarkan hasil assessment lapangan mengenai kondisi masyarakat akan kesadaran untuk meningkatkan pemenuhan gizi protein hewani terutama yang bersumber dari pengolahan daging ikan. Desa Cintamulya secara umum memiliki berbagai permasalahan terutama dalam meningkatkan gizi dan pendapatan masyarakat. 
Tingginya jumlah warga yang tidak memiliki pekerjaan dan banyaknya ibu rumah tangga yang tidak memiliki keterampilan yang lain untuk dapat membantu perekonomian keluarga. Melihat pada kondisi tersebut kegiatan pembuatan baso ikan sebagai upaya untuk meningkatkan nilai gizi protein hewani masyarakat desa Cintamulya dan khususnya anak-anak terutama peningkatan gizi protein yang bersumber dari ikan, dan tentu saja juga memberikan keterampilan lain agar dapat memanfaatkan waktu luang untuk menghasilkan produk yang dapat dijual menjadi salah satu solusi yang bisa dilakukan. Bakso ikan ini memiliki potensi ekonomi yang cukup tinggi karena dengan cita rasanya yang khas dan ketahanan dalam penyimpanan akan memberikan suatu peluang usaha yang bisa meningkatkan pendapatan masyarakat (Afriyanto dan Liviawaty 1989).

Dalam hal ini, kesadaran masyarakat dapat ditingkatkan dengan sosialisasi kepada masyarakat akan dampak secara positif yang dihasilkan dan akan dapat meningkatkan potensi perekonomian baru bagi masyarakat bila dikelola dengan baik. Pelaksanaan kegiatan penyuluhan dan praktek pembuatan baso ikan PPMP OKK ini dilaksanakan pada tanggal 21 Oktober 2017 yang bertempat di Balai Desa Cintamulya dihadiri oleh 44 orang peserta yang berasal dari kader PKK dan ibu rumah tangga di lingkungan RW 07 Desa Cintamulya.

Pengembangan program penyuluhan dan pelatihan tentunya dikembangkan sesuai kebutuhan dan karakteristik masyarakat sebagai mitra kerja dengan evaluasi hasil $100 \%$ memiliki tingkat keseriusan, aktif, dan memiliki kreaktivitas yang tinggi (Astawan 2008). Keterbatasan waktu pertemuan mengakibatkan tidak semua materi dapat disampaikan dengan detil. Kegiatan yang di awali dengan ceramah dan demonstrasi ini kemudian dilanjutkan latihan. Acara kemudian dilanjutkan sesi tanya jawab. Berbagai pertanyaan diajukan secara antusias oleh para peserta dalam sesi tanya jawab. Program pengabdian pada masyarakat berupa pelatihan pembuatan baso ikan bagi para kader PKK dan ibu rumah tangga yang sudah dilaksanakan ini diharapkan dapat menambah pengetahuan, keterampilan dan lebih percaya diri. Para peserta pelatihan akan lebih semangat dan termotivasi untuk mengembangkan diri. Hasil pelatihan ini akan bermanfaat bagi diri mereka masing-masing dalam mengembangkan olahan masakan terutama berbahan dasar ikan lebih bervariasi. Hasil kegiatan PPMP OKK secara garis besar mencakup beberapa komponen sebagai berikut:

1. Keberhasilan target jumlah peserta pelatihan

2. Ketercapaian tujuan pelatihan

3. Ketercapaian target materi yang telah direncanakan

4. Kemampuan peserta dalam penguasaan materi

Target peserta pelatihan seperti direncanakan sebelumnya adalah paling tidak 25 ibu-ibu kader PKK dan ibu rumah tangga, dalam pelaksanaannya, kegiatan ini diikuti oleh 44 orang peserta. Dengan demikian dapat dikatakan bahwa target peserta tercapai lebih dari 100\%. Angka tersebut menunjukkan bahwa kegiatan PPMP OKK dilihat dari jumlah peserta yang mengikuti dapat dikatakan berhasil/ sukses.

Ketercapaian tujuan pendampingan pembuatan baso ikan secara umum sudah baik, namun keterbatasan waktu yang disediakan mengakibatkan tidak semua materi dapat disampaikan secara detil. Namun dilihat dari hasil latihan para peserta yaitu sangat antusias dan bersemangat, maka dapat disimpulkan bahwa tujuan kegiatan ini dapat tercapai. Ketercapaian target materi pada kegiatan PPMP OKK ini cukup baik, karena materi pendampingan telah dapat disampaikan secara keseluruhan.

Kemampuan peserta dilihat dari penguasaan materi masih kurang dikarenakan waktu yang singkat dalam penyampaian materi dan kemampuan para peserta yang berbeda-beda. Hal ini disebabkan jumlah materi yang banyak hanya disampaikan dalam waktu sehari sehingga tidak cukup waktu bagi para peserta untuk memahami dan mempraktekkan secara lengkap semua materi yang diberikan. Secara keseluruhan kegiatan pembuatan baso ikan untuk pemenuhan gizi protein hewani masyarakat RW 07 Desa Cintamulya dapat dikatakan berhasil.

Berdasarkan perbandingan dengan faktor-faktor yang merupakan kendala dalam kegiatan ini, ternyata faktor-faktor yang merupakan pendukung/positif lebih banyak dirasakan dalam kegiatan pengabdian ini. Beberapa hal yang merupakan faktor pendukung, antara lain: sasaran sebagai mitra kerja yang sesuai kebutuhan dan karakteristiknya. Karena itu kegiatan ini mengisyaratkan untuk senantiasa dilakukan secara periodik, sistematis, dan berkesinambungan.

Program kegiataan ini tepat sasaran, sebab ternyata khalayak sasaran sebagai mitra kerja sering mengalami kesulitan dalam mengolah produk perikanan agar disukai oleh anak-anak. Dengan kegiatan ini khalayak sasaran memperoleh pengalaman dan keterampilan yang sangat berharga untuk keberhasilan peningkatan kesejahteran keluarganya, dengan melalui keinginan berwirausaha yang berkelanjutan.

Setiap kegiatan tentu ada faktor penghambat dan faktor pendukungnya. Meskipun demikian, secara umum dapat dikatakan bahwa kegiatan pengabdian pada masyarakat berupa pelatihan ini tidak terlalu banyak mengalami hambatan dan kendala. Hal-hal yang mungkin merupakan hambatan berkisar pada hal yang bersifat teknis berkenaan dengan waktu pelaksanaan dan faktor terbatasnya anggaran untuk kegiatan ini.

\section{SIMPULAN}

Program PPMP OKK dapat diselenggarakan dengan baik dan berjalan dengan lancar sesuai dengan rencana kegiatan yang telah disusun meskipun belum semua peserta pendampingan menguasai dengan baik materi 
yang disampaikan. Kegiatan ini mendapat sambutan sangat baik terbukti dengan keaktifan peserta mengikuti pendampingan dengan tidak meninggalkan tempat sebelum waktu pelatihan berakhir. potensi pengolahan produk daging ikan untuk menjadi baso ikan bukan hanya dapat mengembangkan pola pemikiran masyarakat akan peningkatan gizi protein hewani, namun juga berpengaruh terhadap kemajuan sosial ekonomi masyarakat Desa Cintamulya. Sebagaimana diketahui juga dengan pelatihan ini dapat meningkatkan keterampilan ibu-ibu rumah tangga dan PKK dan mengisi banyaknya waktu luang yang mereka miliki.

\section{UCAPAN TERIMA KASIH}

Penulis mengucapkan terima kasih kepada Direktorat Riset, Pengabdian Pada Masyarakat dan Inovasi Universitas Padjadjaran yang telah memberikan dana hibah Pengabdian Pada Masyarakat Prioritas Olah Raga, Kesenian dan Kreativitas, ucapan terima kasih disampaikan kepada pemegang kebijakan (Kepala Desa, Ketua RW dan RT) dan masyarakat di RW 07 Desa Cintamulya sehingga program pengabdian ini dapat terlaksana dengan baik.

\section{DAFTAR PUSTAKA}

Afriyanto, E \& Liviawaty, E. 1989. Pengawetan dan Pengolahan Ikan. Yogyakarta: Kanisius.
Almatsier, S. 2009. Prinsip Dasar Ilmu Gizi. Jakarta: PT Gramedia Pustaka Utama.

Astawan, M. 2008. Sehat Dengan Hidangan Hewani. Jakarta: Penebar Swadaya.

Bintoro, V.P. 2008. Teknologi Pengolahan Daging dan Analisis Produk. Semarang: Universitas Diponegoro.

Cahyadi. 2006. Analisis dan Aspek Kesehatan Bahan Tambahan Pangan. Jakarta: Bumi Aksara.

Balia, R.L., Suryaningsih, L. \& Putranto, W.S. 2014. Pengajuan Pemalsuan Bakso dengan Daging Babi Melalui Pendekatan Enzimatis dan Molekuler pada UKM Di Kawasan Pendidikan Jatinangor Kabupaten Sumedang. Dharmakarya: Jurnal Aplikasi Ipteks untuk Masyarakat. 3, (2), 70-72.

Widyasanti, A., Putri, S.H. \& Dwiratna, S.N.P. 2016. Upaya Pemberdayaan Masyarakat Melalui Pelatihan Pembuatan Produk Sabun Berbasis Komoditas Lokal di Kecamatan Sumakamantri Ciamis. Dharmakarya: Jurnal Aplikasi Ipteks untuk Masyarakat. 5, (1), 29-33. 